\title{
Agritourism entrepreneurship in Greece: policy framework, inhibitory factors and a roadmap for further development
}

\section{Panagiota Dionysopoulou}

Director General for Tourism Policy, Ministry of Tourism, Greece \& Adjunct Professor of Higher Education, Hellenic Open University, Patras, Greece

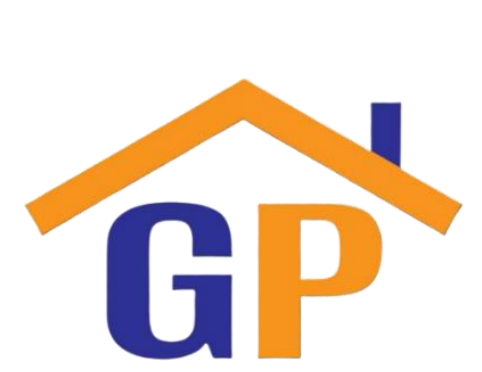

\begin{abstract}
Purpose: This paper aimed to examine how agritourism as a mild form of tourism can contribute to sustainable tourism development.

Research methodology: A primary survey was conducted using a closed-type questionnaire of multiple-choice questions and sent to a respective enterprise sample.
\end{abstract}

Results: The survey's output refers to the steps and measures that need to be taken for the further development of agritourism in Greece and its driving force as a pillar of sustainability growth.

Limitations: The research addressed certain methodological issues,

Article History

Received on 29 December 2020

$1^{\text {st }}$ Revision on 25 February 2021

$2^{\text {nd }}$ Revision on 16 March 2021

$3^{\text {rd }}$ Revision on 28 March 2021

Accepted on 30 March 2021 such as the difficulty of collecting the sample, since agritourism companies are not in total registered in Greece. There was also difficulty obtaining contact details (email, fax) from the list of final approved investments of the National Strategic Reference Framework.

Contribution: The purpose is to present the views of agritourism entrepreneurs on their industry and identify the possible problems they encountered during their businesses' start-up and operation due to the legal or financial framework. Also, the state's role in this direction is examined and proposals are made for the further development of agritourism in Greece.

Keywords: Farmer, Law 4276/2014, Legal framework of agritourism, National strategic reference framework, Rural tourism, State aid, Sustainable development

How to cite: Dionysopoulou, P. (2020). Agritourism entrepreneurship in Greece: policy framework, inhibitory factors and a roadmap for further development. Journal of Sustainable Tourism and Entrepreneurship, 2(1), 1-13.

\section{Introduction}

Agritourism belongs to rapidly developing alternative forms of tourism and is one of the Greek economy's most competitive and qualitative sectors. It meets the demands of modern man, returning to his roots, contact with nature, tradition and the simple philosophy of life that has lost in recent years and at the same time promotes the model of sustainable tourism development, enhancing the local economy, creating jobs without altering the cultural, social and environmental characteristics that highlight the uniqueness of the place. Greece is suitable for developing alternative forms of tourism, as each region has a rich natural wealth, architecture, historicity, classical and modern, unique and unique local products. For the proper functioning of the system, it is necessary to adopt policies that promote sustainability, mild tourist development and respect for cultural and national identity.

By its very nature, tourism is an area that affects and is influenced by distinct individual policies. It requires cooperation and co-ordination of them for its integrated approach, with a view of the product's quality production and distribution. It is worth highlighting the importance of the legal framework for the operation of agritourism and criticizing and formulating proposals to extend the 
application of this specific and alternative form of tourism as it contributes to the sustainability and development of local societies. In the countries strategically integrated into their national planning, agritourism has improved the mix of services offered by giving them a distinctive character and personality in their offshore areas.

The key objective of this article is to investigate the impact of the current national legal regime, which incorporates the directives, rules, and guidelines of the European Union regarding its real contribution and especially its degree of effectiveness in Greek Agritourism development. Proper legal regime is needed to run and develop agritourism, as happened in every good foreign country example. This research's real contribution reveals the proper measures to be taken to enlarge the contribution of agritourism in the Greek tourism and local economy. In order to analyze the existing theoretical framework for identifying the meanings of agritourism, the section following deconstructs several definitions of agritourism and presents a discussion of the efforts put forth by Phillip et al. (2010) to construct a broad definition of agritourism.

Definitions of agritourism are wide-ranging in the literature. The discrepancies found among the various agritourism definitions relate to three issues: (1) the type of setting (e.g., farm, any agricultural setting); (2) the authenticity of the agricultural facility or the experience; and (3) the types of activities involved (e.g., lodging, education). A fourth ontological issue was proposed to be added, related to the need of "travel", given the use of the word "tourism" (agritourism) in its label (Arroyo, Barbieri, \& Rich, 2013).

The type of setting where the activity occurs forms a big difference in agritourism definitions. The majority of studies claim that agritourism must be carried out on a farm (Carpio et al., 2008; $\underline{\text { Ilbery, }}$ Bowler, Clark, Crockett, \& Shaw, 1998; McKenzie \& Wysocki, 2002). But, there are few studies discussing different type of agricultural settings, such as farms, ranches (e.g., Che et al., 2005; Tew \& Barbieri, 2012) or the inclusion of some types of off-farm facilities, such as farmers' markets, where various kinds of farm products are taken away from the agricultural production setting to be sold (Wicks \& Merrett, 2003; Wilson, Thilmany, \& Sullins, 2006). Furthermore, there are different meanings used to define agricultural establishments, especially those related to "farm". European Union defines a farm as an agricultural holding, meaning "economic unit under a single management engaged in agricultural production activities" and which can also engage in non-agricultural activities (OECD, 2001). Finally, thanks to academic developments over last decades there is a clear separation between terms "agritourism" and "rural tourism" (Colton \& Bissix, 2005; Kizos \& Iosifides, 2007; McGehee \& Kim, 2004).

A second commonly found disagreement surrounds the authenticity paradigm related to the agricultural facility and to the experience offered (Arroyo, Barbieri, \& Rich, 2013). McGehee (2007) based her agritourism development framework in the U.S. on Weaver and Fennell (1997) 's definition, which explicitly excludes activities and experiences developed in non-working farms deem necessary the commercial aspect involved in this activity. Furthermore, various North American (Lobo et al.,1999; McGehee \& Kim, 2004; Nickerson et al., 2001; Tew \& Barbieri, 2012) and European (Hegarty \& Przezborska, 2005; Kizos \& Iosifides, 2007; Sonnino, 2004) studies claim that having a "working" agricultural setting is linked to recognizing this activity as one form of entrepreneurial farm diversification (Barbieri, Mahoney, \& Butler, 2008). Phillip et al. (2010) expanded the authenticity debate in the context of tourist experiences by adopting MacCannell's (1973) "front" and "back" regions of authenticity theory. The particular study refers to the difference between providing the visitors an indirect experience of agricultural activities (e.g., through demonstrations, models) from a direct engagement in an agricultural process (e.g., harvesting).

A third definitional disagreement relates to the activities that agritourism comprises which is not surprising given the extent of inconsistencies related to its meaning. Such inconsistencies may be geopolitical as they seem to be associated with government policies (Arroyo, Barbieri, \& Rich, 2013). Finally, Arroyo et al. (2013) suggested the addition of an ontological discussion surrounding the definition of agritourism to the preceding debate in relation to the need of "travel", especially because the term "tourism" is embedded in the label most commonly used in the literature to depict this activity (agritourism). None of the agritourism definitions reviewed refers to the need for travel; however, some of them may imply some sort of travel when mainly referring to farm-stays or entailing any type of accommodations.

2020 | Journal of Sustainable Tourism and Entrepreneurship/ Vol 2 No 1, 1-13 


\section{Literature review}

\subsection{An approach on agritourism}

Agritourism is not identical to rural tourism but is part of it, along with other alternative forms such as ecological, environmental, healing, adventure tourism, and others (Bazin and Roux, 1997). The agritourism product is the combination of services, products, and activities directly or indirectly linked to the particular rural, social, cultural and environmental characteristics of the agritourism destination and highlights its peculiarities (Logothetis, 1988).

There are two forms of agritourism in Greece (www.gaiapedia.gr/gaiapedia/index.php). The forms of pure agritourism are in villages of particular natural beauty (mountainous and not) that attract visitors, utilizing the beauty of their location, in islands or coastal areas that mainly use the sun and sea in the summer months in traditional settlements have a special architecture in protected areas such as national forests and wetlands that, in addition to natural beauty, undertake to enrich visitors' knowledge of ecology and in cooperative housing, where members of cooperatives, mainly women, offer products of their own or local production and authentic hospitality. The forms of complex agritourism are in areas with thermal springs, known as spa resorts, wherein special hydrotherapy resorts tourists are subjected to some treatments, in mountain villages with a possible organized ski center which is also the attraction of tourists in rural areas with recreational- sports facilities, camping camps, located in the vicinity of rural settlements and with which they are socially and culturally connected, in centers of intercourse tourists who are located in special hubs and accept passers-by to offer them hospitality in rural areas where there are cultural interests.

According to the official website of the Association of Agritourism Associations in Greece, the agro touristic destination is a rural area, which constitutes "a distinct geographical and/or administrative unit, morphologically and historically, which does not include settlements of more than 3,000 inhabitants (this criterion is calculated per settlement and not across the region)its inhabitants mainly deal with the primary sector (agriculture, livestock farming, fisheries)", and "there has not been developed within this area a tourist offer of mass (i.e. organized tourism) tourism or an offer aimed at the demand for other non-mild forms of tourism in accordance with defined by the competent national authorities, except for examples of traditional settlements, the settlements with particular characteristics have developed a significant activity in agritourism and the development of mass tourism does not affect them." (Agrotourism, 2008).

The agritourism enterprise, as recorded on the website of the Association of Agritourism Associations of Greece, is a diversified tourist enterprise that develops small-scale infrastructure projects with mild interventions in the environment and provides accommodation, catering, recreation, touring, touring, reviving the traditional way of life the visitor to acquaint the rural area and the agricultural activities as well as the production processes that have disappeared, the cultural elements and the authentic features s place, local products, traditional cuisine and daily life of the rural residents. Nevertheless, even before the five years period of 2005-2010, there was, unfortunately, a distortion of the agritourism object, since in many areas entrepreneurs got involved and built luxurious accommodations without any respect for the environment and the cultural features of each place (Katsoni, V. et al., 2018). Gastronomy is an integral part of the qualitative and integrated provision of agritourism. The offered food must combine the good quality with the quantity and variety, coming from traditional recipes. A prerequisite must be the use of local products, with no flexibility and exceptions.

\subsection{The evolution of the legal framework}

Special tourism legislation in Greece started quite early in the early 19th century. The first law was Law 241/1914 and later Law 1698/1919, "Regarding the organization of its operation, according to Law 241/1994, a separate Foreign and Foreign Office," which laid the foundations for the subsequent establishment of the Hellenic Organization Tourism (EOT). The establishment of the Greek Tourism Organization in 1929 was a focal point in the development and development of tourism in our country and the establishment of the Tourist Police in the same year. The Greek Tourism Organization was replaced in 1945 by the General Secretariat for Tourism and re-established in 1950 . 
It belongs to the Regional Tourism Services of the Ministry of Tourism ${ }^{1}$, and has the responsibility of displaying the tourist product. The Ministry of Tourism is responsible for defining the policy aimed at the country's tourism development, while for the development of special forms with the creation of thematic products, it cooperates with the Ministry of Rural Development and Food (Ministry of Rural Development and Food), (L241/1914).

Agritourism is a special form of rural tourism that involves the provision of reception and hospitality services and/or catering services in functionally integrated rural areas, which are combined with activities related to agricultural production as well as the protection and enhancement of the natural and anthropogenic rural landscapes (Article 28 of Law 4279/2014) (Article 4 para.3N.4582/ 2018). The activity of agritourism is necessarily combined with the production of agricultural products within the meaning of article 2 of Law 3874/2010 by farmers included in the Register of Farmers and Agricultural Holdings (MAEE) maintained by the Ministry of Agriculture and Rural Development, as mentioned in the provisions of Law 4582/2018. The National Register of Agricultural Cooperatives and other Collective Organizations under Article 19 of Law 4384/2016 is a continuation of the National Register of Agricultural Cooperative Organizations and Interprofessional Organizations established by Article 2 of Law 4015/2011.

Law 4276/2014 Government Gazette A 155 30-7-14, as supplemented by Law 4582/2018, and Joint Ministerial Decisions B 1145 3-4-2017, Joint Ministerial Decision 12528 / 30-7-2018 on Multifunctional Farms and the creation of a CSF, respectively, is an effort to replenish the gap, as it places particular emphasis on rural tourism and its subcategories. They clearly define the operating procedures of tourism businesses, their conditions and infrastructure. As defined in Article 29 of Law $\underline{4279 / 2014}$, the possible forms of agritourism are farms, rural, mixed farming and livestock holdings, and agricultural, livestock and habitats cooperatives. When businesses provide catering services, they only have to use products from the Basket of Agricultural Products.

Basket of Agricultural Products is the set of selected primary food products (agriculture, forestry, livestock, fisheries and aquaculture - mining and freshwater), whose production and / or processing and/or standardization occurs within the administrative boundaries of the Region. As a basket of agricultural products is also meant the basket of the Region within the meaning of Law 4015/2011. The relevant Regional Council is the body responsible for institutionalizing and defining the contents of the basket of agricultural products of a region. (Article 29 (5) of Law 4279/2014).

The farm is defined as the operationally integrated site of the farmer, registered in the MAEE (Register of Farmers and Rural Farms) under the current system and has land/plot autonomy as in the multifunctional farms of Article 52 of Law 4235/2014s, the difference of which lies in the connection of primary production with the processing stage and the provision of services. Development Law $\underline{4399 / 2016}$ concerns the modernization and/or extension of tourist accommodation and facilities for special forms of tourism.

\subsection{The route of agritourism in Greece}

The development of agritourism in Greece in the 1980s was marked by the country's entry into the European Economic Community (EEC). The Common Agricultural Policy (CFP) has been a primary concern among the policies chosen in accordance with the principles governing its founding treaty. Its aim was to make food available to European consumers at affordable prices and ensure the European rural population (Wikipedia, 2018). Over the years that followed, and in the context of fermentation with other distinct policies in the fields of European cooperation, the CAP has evolved to respond to social and economic policies (Mousis 2001). Within the European Union, agritourism was initially treated as an activity of a local and regional nature that was able to contribute to the reconstruction of rural areas by preventing its depopulation, giving way to the economic suffocation of disadvantaged areas and proposing an alternative solution to locals where their primary source of income is exclusively the primary sector (Iacovidou, 1999).

\footnotetext{
${ }^{1}$ www.mintour.gov.gr/Ministry/VisionMission/
} 
In the next decade, the effort was reinforced with the 2nd Community Support Framework (CSF II) and in particular with Regulation 2328/91, with the Regional Operational Programs, the Regional Operational Programs, through which private investment in rural tourism was strengthened (Developmental Parnon-Developmental 2018), as well as the Objective 5b programs of the European Union. The Department for Environment, Food and Rural Affairs (DEFRA) established the "Rural White Paper," which included actions in this direction (Natural Environment White Paper 2011).

\subsection{Legal framework $\mathrm{EU}$}

The Treaty of Maastricht in 1992, Article 2 of the Treaty, decides to implement common policies within the EU that will lead to the promotion of economic activities with full respect for the environment (European Union, 2016). In 1992, the European Commission adopted Directive 90/314 / EEC, which establishes common rules for package travel and removes obstacles arising from different legal frameworks arising in the individual Member States. Our country incorporated it on 11-09-1996. (Council of the EEC, 1990) In 1992, the European Commission adopted Directive 90/314/EEC, which establishes common rules for package travel and removes obstacles arising from different legal frameworks arising in the individual Member States and which our country incorporated it on 11-091996 (Council of the EEC, 1990).

The Leader Programs (Liaisons Entre Actions for Development of the Economics Rurale - Links between actions for the development of the rural economy) have been the largest provider of agritourism. Their strategic objective was and remains to provide incentives for investment proposals in disadvantaged areas of the country. They began to be implemented in 1992, (the 1992-1996 Programming Period) in Greece and in Europe, which was the beginning of a new approach to rural development policies. The AgroTourNet subprogram (1995), in which Greece participates, was set up to attract investment, certify agritourism accommodation, and use ICT (Information and Communication Technologies, e.g. the Internet). LEADER II was a more systematic and integrated program during the 1996-2000 Programming Period, while LEADER + during the 3rd Programming Period (2000-2006) succeeded in introducing and enhancing partnerships between local actors and social partner groups.

Another program for agritourism is the Integrated Rural Development Programs (OPAA), which are controlled by the Ministry of Rural Development and are in line with the terms and conditions of the EU, have been included in the 3rd Community Support Framework with a time horizon of 20002006, and were an innovative proposal for rural development as they included 14 measures, most of which were elaborated under Article 33 of Regulation 1257/99 and applied to selected mountainous and less-favored areas of the country. In the Treaty of Lisbon in 2007, a coherent framework is established whereby the competitiveness of tourism enterprises can be promoted jointly (European Union, 2007).

Law 3658/2008 "Measures for the Protection of Cultural Property and Other Provisions" (Maniatis, 2016), which emphasizes the importance of agritourism in coastal, mountainous and island regions, is considered to be the corresponding legislation in Greece. It is possible to link a place or a wider area with thematic tours at local, national and European level through thematic tourism. It is also a measure for developing cooperation between regions and states and reducing the seasonality of tourism, especially in the Mediterranean countries. The 2007-2013 rural development program, created in accordance with Council Regulation (EC) 74/2009 of 19 January 2009, focused on three main pillars, the optimal presentation of competitiveness in the agricultural and forestry sectors, the protection of the environment and rural areas and improving the quality of life of rural areas and diversifying their economies, with the support of a LEADER fourth horizontal axis based on the experience of previous LEADER Community Initiatives.

European Tourism Indicators Systems (ETIS), presented by the EU in 2013, are the European indicators for the sustainable management of European tourist destinations. Maintaining safety standards for tourism businesses is an element of their high quality and the Green Paper of the European Commission entitled "Safety of tourist accommodation services" is welcomed (Maniatis, 2016). Parliament's Resolution 2014/2241 (INI) highlights the importance of agritourism as a determinant of sustainability and growth. In particular, it is emphasized that tourism must be based on strategies that protect and enhance natural resources and cultural heritage by promoting and preserving 
local folk traditions and local culture and tradition and local products and preserving the cultural of this heritage (European Parliament, 2015). For the 2014-2020 programming period, LEADER retains the key element of the bottom-up approach to the design of multidisciplinary local strategies, while giving the opportunity of a multidisciplinary approach as well as the widening of the application areas.

The Rural Development Program (RDP) for the 2014-2020 programming period envisages the "Integrated development and sustainable competitiveness of rural areas" and aims at protecting the environment, enhancing the competitiveness of the agri-food sector, and highlighting the multifunctionality of rural regions. The Action "Strengthening the Establishment and Operation of New Tourist Small and Medium Enterprises" of the Operational Program "Competitiveness, Entrepreneurship and Innovation (EPANEK)," National Strategic Reference Framework 2014-2020 aims to strengthen entrepreneurship in the tourism sector by creating new micro, small and mediumsized tourism enterprises in selected CSR activities. (ERDF \& CF Special Secretariat / Special Management Office of the Operational Program "Competitiveness and Entrepreneurship").

Local Development with Community-Led Local Development (CLLD) is based on LEADER. It is mentioned as a method of designing and implementing integrated, local, developmental strategies, involving both local social and economic actors as well as civil society, in order to effectively address the economic, social, demographic and environmental issues that arise frequently, and are urged to resolve local communities (Iakovidou, 1999). Kilkis Development S. A. is an example of a company aiming at the local and regional development though the most effective use of the EU funding tools and programs such as LEADER.

\section{Research methodology}

The objectives of primary research are to identify the profile of agritourism enterprises and to self-assess their place of activity. On the other hand, the recording of the views of the entrepreneurs themselves about their industry and the problems they encountered when starting and running their businesses due to a legal or financial framework, clearly capturing the strengths, weaknesses and issues that need to be met are researched and also the possibility of free training on entrepreneurship issues by the stakeholders.

For the data collection, a primary quantitative randomized sampling was selected to ensure representativeness and to reduce the error as much as possible. The layers were composed of homogeneous groups of the population in terms of some features such as accommodation, cooperatives, NSRF funding, etc. Analog sampling was used where a sample was selected from each layer so that the ratio of the size of the sample to the layer to size of the total sample is equal to the ratio of the size of the population of the layer to the size of the total population.

In the present study, 30 qualitative closed-ended questions were selected, of which 21 were single-choice, 5 Likert questions and 4 questions of the scale. The questionnaire was mixed and the main objective was to explore the entrepreneurs' view of their industry, which category they believe fit under the categorization of Law 4276/2014, the evaluation of the procedures for financing and subsidizing the initial investment costs, the operation of the units, the operation of their units to date and generally the positive and negative points of the legal framework for the establishment and operation of such alternative tourism units and their possible proposals.

The population was 650 agritourism enterprises in the country, large enough to reduce the sampling error, and mainly because of the fear of non-response from all units in the sample that eventually proved correct. Agritourism companies selected are 100 listed agrotourist accommodation, the Association of Agritourism of Greece (SEAGE), 141 Agricultural Cooperatives of Greece, through the "Agritourism, Crafts and Trade Union Cooperatives of Greece", supported by the Ministry of Rural Development and Food (Ministry of Rural Development and Food) and 409 businesses (hostels, farms, visiting farms, wineries, etc.) operating in the industry, while 180 businesses answered.

The survey time was about 3 months (March-May 2018). Search for locating "agritourism enterprises" carried out on the Ministry of Agriculture and Rural Development and the Association of Agritourism Unions of Greece and thoroughly check the above data to avoid duplication. The contact details (email, fax) found from the table of definitively approved NSRF investments. The survey was conscious of the consent of respondents who were fully informed by an introductory letter to the 
questionnaire sending email for the purposes of the survey and the use of their replies. In addition, there were related confidentiality commitments.

\section{Results and discussions}

According to the survey results, agritourism in Greece is not exercised exclusively by farmers, but also by other natural or legal persons who have no initial relationship with the agricultural sector. These are small, family-run businesses, usually houses, small houses, farms or farms that do not exceed 5 acres and up to 10 rooms and 40 beds, and as 2 different crops and 3 indigenous or local animal breeds.

$68 \%$ are business owners, either owning it independently by $10,6 \%$ or with $1-4$ family members by $63,8 \%$. Few agritourism businesses are investing and doing business with owners with other main occupations, possibly with a permanent residence, usually out of their place of operation. This is also verified elsewhere in the survey where 55,3\% declare that they are not a farmer and 54,3\% claim to have an OAEE (Occupational Insurance Organization) insurance fund. In comparison, 44,7\% respectively declare themselves to be the main occupation of farmer, is confirmed by $45,7 \%$ which has the insurance fund of OGA (Agricultural Insurance Agency).

More than half of businesses (51\%) are active over 10 years, while others have started operating within the last decade's economic crisis. Of most of them, 52\% of businesses are traditional hospitals focusing on food, while $31 \%$ are Cooperatives, visiting wineries, olive-growing, animal husbandry, local produce production/processing, and others. A significant percentage of $17 \%$ are multifunctional farms.

As shown in figure 1 below, most of the $55.1 \%$ agritourism businesses offer $51.1 \%$ residence and production activity, some processing them at $19.1 \%$ (fewer than the producers), a significant $34 \%$ has a sales outlet, while a $27.7 \%$ offers focus. The percentage of those who offer education/participation in production is $17 \%$, while those involved in entertaining activities account for $31.9 \%$.

\section{Memorandum}

(top to bottom)

1. Production of products

2. Processing

3. Sale

4. Focus

5. Accommodation

6. Accommodation and training/production participation

7. Accommodation and other recreational activities

Figure 1. Services provided by agritourism businesses (percentage)

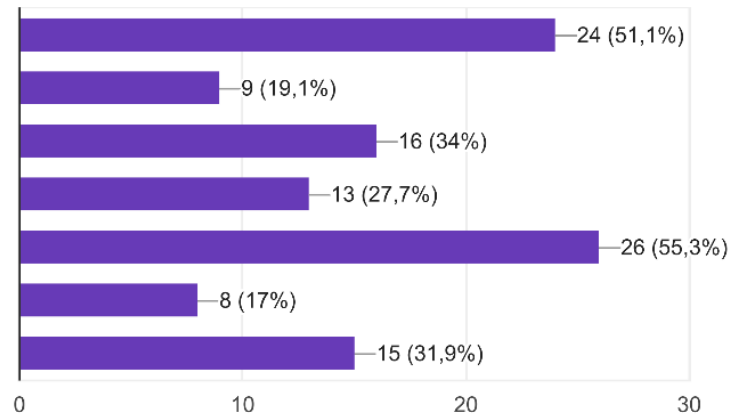

Source: developed by the authors based on data of the survey

Engaging in agritourism is mainly a female affair, with a declared or indiscriminate offer of work, assisted by all family members. The main purpose is to supplement the family income and adopt the agritourism philosophy and emotional ties with the family. The age group that dominates agritourism is between 35 and 50 years with $59.6 \%$, while a significant percentage of $25.5 \%$ is between 
25 and 35 years. This practically means that the most productive human resources groups are engaged in this form of tourism, a development that is considered very encouraging because it can contribute to the development of the agricultural sector with a positive impact on the local community since it creates the appropriate incentives and conditions for to prevent the permanent population from moving.

Also interesting is the percentage of employed over 50 years, which is down $10 \%$, as well as those who are up to 25 years of age, reaching $4.3 \%$. Remarkably, the solar team is over 65 . On the one hand, this finding can mean the undeclared work of the smaller ones, such as students; on the other hand, for the older ones, the concession of the company to the family circle due to retirement with possible implicit participation.

Figure 2. Employed per age group (percentage)

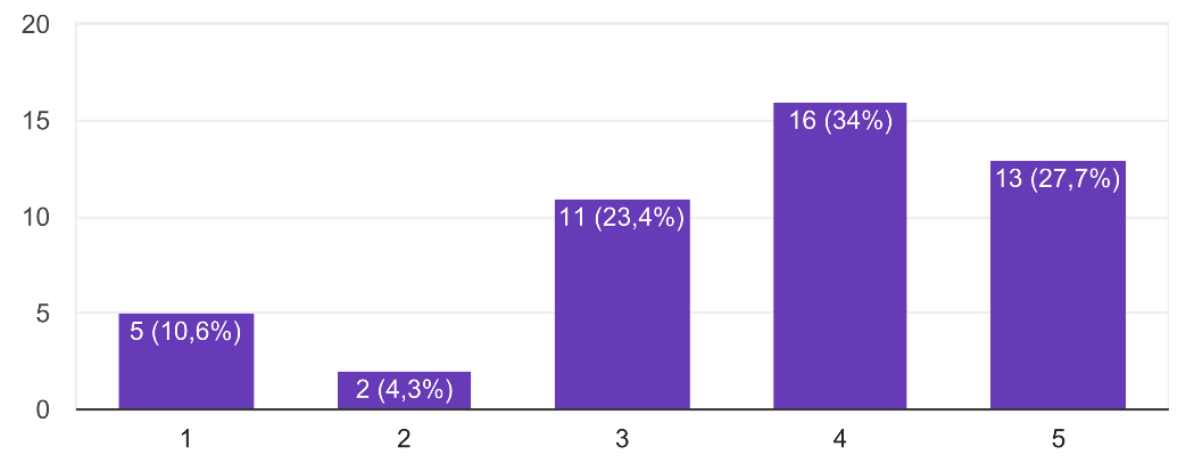

Source: developed by the authors based on data of the survey

This finding, which relates to the possible active participation of older members of the wider family, is strengthened if combined with figure 2 above. Most of them said they are sufficiently experienced in agritourism. The survey has shown that the majority advocates the Greek countryside's uniqueness, which is reflected in climate, natural resources, local cuisine, cultural attractions, which are excellent or very good level, and are considered strong points. While the shortcomings are noted, the difficulty of offering learning seminars, such as the possibility of taking part in agricultural work, preparing regional cuisine, as well as the production of folk art, also the possibility of sports and, above all, the high operating costs of businesses where it is burdened by customers.

The dominant motive for turning to agritourism is the adoption of its philosophy followed by a double conscious personal choice in both lifestyle and business. The vast majority of it $71.7 \%$ said that emotional reasons were the motivators, while $18.9 \%$ treated it as a livelihood emergency and only $9.4 \%$ thought to take the opportunity financing.

Summarizing that most of them were experienced in business, they had decided to invest in the field of agritourism due to philosophy; there is a tendency to reconstruct a productive model by highlighting the productive potential and investment opportunities, which is particularly encouraging. On the contrary, the absorption of available EU funds through the National Strategic Reference Framework programs is extremely low. Although the majority had knowledge and experience in entrepreneurship, the legal framework of agritourism has been pointed out by all as incomplete, the start-up, operation and subsidy procedures of a business have been characterized as time-consuming and challenging, which has prompted several to own resources. 
Figure 3. Comprehension of the legal framework (percentage)

20

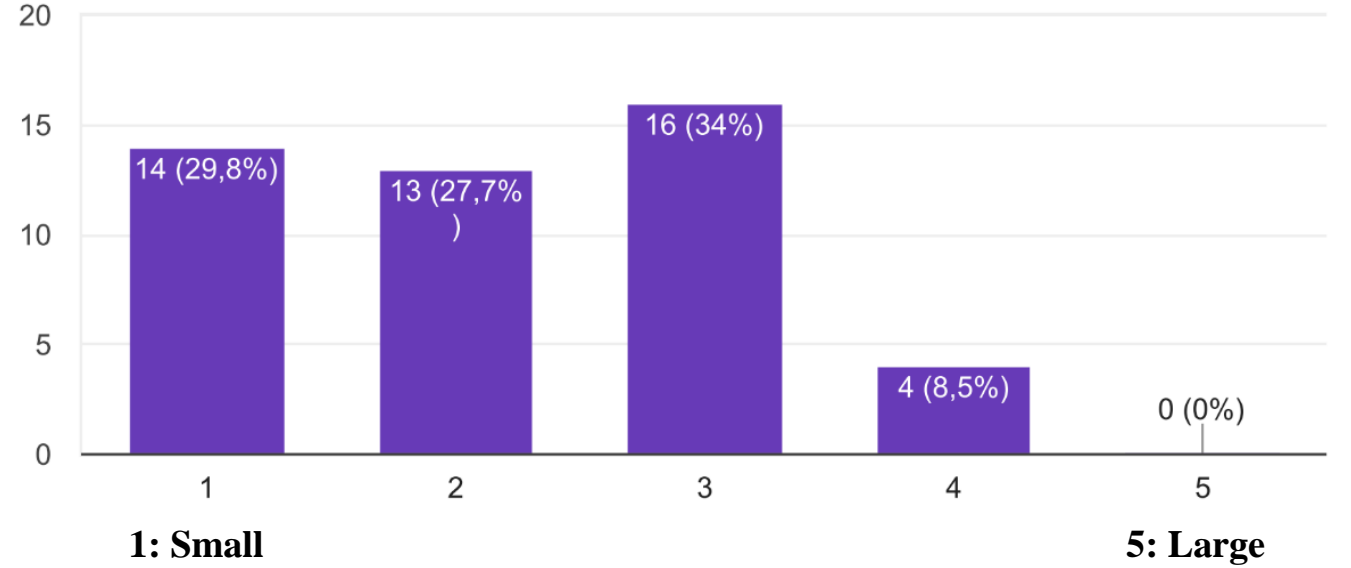

Source: developed by the authors based on data of the survey

As shown in figure 1 above, the most the respondents have difficulty in understanding the legal framework, while only $8.5 \%$ consider that they are quite clear (grade 4), while the answer to full clarity (grade 5) is absent. Regarding the information on start-up procedures, most of them, consider that they have little or no adequate information from official bodies, such as the relevant ministries and the Greek National Tourism Organization, but also from the Agritourism Associations, Cooperatives, PanHellenic Association of Young Farmers and Business Consultancy Companies.

The time required to start/license a business is one year. The highest percentage $(44.7 \%)$ considers the start-up procedures for an agritourism business much more difficult than its original forecasts. However, this has made it harder for most, at this stage of the start of the operation, with $68.1 \%$ being the bureaucratic authorization procedures, the lack of advisory support, with $36.2 \%$, the bureaucratic procedures for financing, with a rate of $34 \%$, the obligation to issue and produce a plethora of documents, the absence of a clear legal framework for agritourism were the points they identified as a hindrance in the development of agritourism in our country. Also, the lack of know-how (23.4\%) was a major factor of difficulty in setting up an agritourism enterprise. The areas selected that need improvement are first and foremost, the licensing procedures, the funding procedures and training followed and a large percentage of $40.4 \%$ chose to transfer know-how and counseling support for agritourism.

Most of the basic funding comes from the own recourses and the family and few have resorted to financing and even less to borrowing. Those who opted for funding said they needed up to a year to disburse. Most of them, also, has invoked the assistance of National Strategic Reference Framework (NSRF) and State Aid consultancy companies, highlighting the difficulty of managing the entire application process. The lack of information and knowledge of funding programs $(11 \%)$ or the inability to gather the required supporting documents $(13 \%)$ were minor reasons.

The financial crisis of recent years has affected businesses both in their booking /sales, in the areas of payment of liabilities and in liquidity in general. But acceptance by most that investments in rural tourism are profitable or will be made from the next six months to four years, and combined that the majority of companies have been operating for over 10 years, it appears that the industry can cope with the difficulties and have a promising future contributing effectively to the economic prosperity of the country and its inhabitants.

In the end, most of the respondents agree that all the individual sectors that contribute decisively to the operation of a rural tourism business need to be improved, giving priority to information and support in promoting and promoting agritourism activity in general and the clarity of the legislative framework. 


\section{Conclusion}

According to our research findings, we conclude that agritourism in Greece is very particular, as it is not a professional activity undertaken exclusively by farmers mainly for employment and insurance but also by other natural or legal persons that do not have an initial relationship with the agricultural sector. As already mentioned above, we faced certain limitations as we carried out this research. The questionnaire, the most flexible research tool, which provides many possibilities for expressing the questions, was adapted to agritourism entrepreneurs in Greece. The sample was 650 agro-tourism companies in the country- too large- in order to reduce the sampling error. Though, as far as the methodology is concerned, there were difficulties on the collection of the sample, since agritourism companies are not in total, registered in Greece. Future research on the following topics would be useful:

1. the factors that would encourage more young people (the productive base of the country and the level of development) to be more engaged in agritourism-such as an extensive survey among high school and high school students on their knowledge, perceptions and suggestions for agritourism.-

2. the creation of a specialized model of agritourism for each region of our country based on its special features, uniqueness, and advantages since natural beauty, history, tradition, gastronomy, and architecture differ from region to region.

3. the development and use of ICT tools that will highlight and promote innovative and mainly effective agricultural products, the Greek countryside customs, and will build a network between the entrepreneurs of agritourism.

4. the set-up of a special legislative framework that will consider the particularities of agritourism so that it can be further developed and be one of the driving forces for the development of the Greek economy.

The following recommendations have been proposed for consideration. A significant development towards the development of agritourism would be the modernization of start-up procedures and the acceleration of grant procedures, the safeguarding of appropriate institutional conditions for the promotion of entrepreneurship, so as to make good use of all the funds available in the programs of the European Union.

It is imperative to update the legislation in force, taking into account the particular features of agritourism, particularly tours and sports, the accommodation, production, processing and marketing of agricultural and livestock products. The modern trend towards entrepreneurship requires the lifting of restrictions, which creates distortions in the free operation of the market, but this does not mean that entrepreneurs do not have to comply with the specific requirements-standards and that the legal sanctions.

The quality of the agritourism product should be the main driver for its development, which will be achieved through extroversion, cooperation and healthy competition between local businesses, as well as an expansion of the services offered. An essential step in this direction is the compulsory offer of educational participation by the guest in agricultural activities related to domestic agricultural production, traditions, preservation of agricultural products, local cuisine and traditional art, such as gathering olives, grapes, honey, production of olive oil and wine, milking, feeding of domestic animals to qualify as an agritourism.

Agritourism activity is based on the specificity of each destination, so municipalities, regions and local tourism agencies should play an important role where they have to take the marketing of this particular identity of each locality. Creating a website with tasteful content, including general information on the location and advertising of local production and processing plants, can make an effective contribution in this direction.

Local actors can advise, direct, and provide information or offer training programs on agritourism and good business practice, young potential entrepreneurs, and all employees in the industry who want to strengthen their position in the business.

In order to bring about the development of rural tourism in an area, there is a need for parallel development, improvement and integration of basic infrastructure projects in the most appropriate way, where due respect for nature will be attributed and ideally suited to the landscape. 


\section{Acknowledgment}

To Mrs. Evanthia Notara, for its Master Thesis at the Hellenic Open University, School of Social Sciences: "The European Framework of the alternative form of agritourism and its harmonization with the Greek legislation". To Mrs. Eftychia Christina Aivaliotou, Alternate Director of Department of Statistics, Ministry of Tourism, for her kind contribution and assistance.

\section{References}

Agrotourism, [online] Available at: https://agrotourism.wordpress.com/ [Accessed 15/12/2017].

Arroyo, G. C., Barbieri, C., \& Rich R. S. (2013). Defining agritourism: A comparative study of stakeholders' perceptions in Missouri and North Carolina. Tourism Management, 37, 39-47.

Barbieri, C., Mahoney, E., \& Butler, L. (2008). Understanding the nature and extent of farm and ranch diversification in North America. Rural Sociology, 73 (2), 205-229.

Bazin G., Roux B. (1997). L' agritourisme: un atout pour les zones rurales difficiles mediterraneennes. Paris: Harmatta

Carpio, C., Wohlgenant, M., \& Boonsaeng, T. (2008). The demand for agritourism in the United States. Journal of Agricultural and Resource Economics, 33 (2), 254-269.

Che, D., Veeck, A., \& Veeck, G. (2005). Sustaining production and strengthening the agritourism product: linkages among Michigan agritourism destinations. Agriculture and Human Values, $22,225-234$.

Colton, J. W., \& Bissix, G. (2005). Developing agritourism in Nova Scotia: issues and challenges. Journal of Sustainable Agriculture, 27 (1), 91-112.

Council Directive 90/387/EEC of 28 June 1990 on the establishment of the internal market for telecommunications services through the implementation of open network provision OJ L 192, 24.7.1990, p. $1-9$

Council Regulation (EC) No 1257/1999 of 17 May 1999 on support for rural development from the European Agricultural Guidance and Guarantee Fund (EAGGF) and amending and repealing certain Regulations OJ L 160, 26.6.1999, p. 80-102

Council Regulation (EC) No 74/2009 of 19 January 2009 amending Regulation (EC) No 1698/2005 on support for rural development by the European Agricultural Fund for Rural Development (EAFRD) OJ L 30, 31.1.2009, p. 100-111

Council Regulation (EEC) No 2328/91 of 15 July 1991 on improving the efficiency of agricultural structures OJ L 218, 6.8.1991, p. 1-21

European Parliament resolution of 29 October 2015 on new challenges and concepts for the promotion of tourism in Europe (2014/2241(INI) OJ C 355, 20.10.2017, p. 71-85 [online] Available at: www.europarl.europa.eu/sides/getDoc.do?pubRef $=-$ //EP//NONSGML\%2BCOMPARL\%2BPE6.843\%2B02\%2BDOC\%2BPDF\%2BV0//EN/, [Accessed 29/3/2018].

European Union, (2016). Treaty on European Union. [online] Available at: www.europa.eu/eulaw/decisionmaking/treaties/pdf/treaty_on_european_union/treaty_on_european_union_el.pdf,\%20\%CE\%9 7\% $\%$ BC\%CE\%B $\%$ CF\%81\%CE\%BF\%CE\%BC\%CE\%B7\%CE\%BD\%CE\%AF\%CE\%B1/ , [Accessed 29/3/2018].

European Union, Treaty on European Union (Consolidated Version), Treaty of Maastricht , 7 February 1992, Official Journal of the European Communities C 325/5; 24 December 2002, available at: https://www.refworld.org/docid/3ae6b39218.html [Accessed 30/3/2018]

Gaia epixeirein, [online] Available at: http://www.gaiapedia.gr/gaiapedia/index.php/\%CE\%9C\%CE\%BF\%CF\%81\%CF\%86\%CE\%A D\%CF\%82 \%CE\%B1\%CE\%B3\%CF\%81\%CE\%BF\%CF\%84\%CE\%BF\%CF\%85\%CF\%81\% CE\%B9\%CF\% 83\%CE\%BC\%CE\%BF\%CF\%8D, [Accessed 20/2/2018].

Hegarty, C., \& Przezborska, L. (2005). Rural and agri-tourism as a tool for reorganizing rural areas in old and new member states e a comparison study of Ireland and Poland. International Journal of Tourism Research, 7 (2), 63-77.

Hellenic Agritourism Federation, 2018, [online] Available at: /www.agroxenia.net, [Accessed $5 / 2 / 2018]$. 
Hellenic Institute of working Health and Safety -Tourism accommodation, [online] Available at: www.elinyae.gr/el/category details.jsp?cat id=3764, [Accessed 15/11/2017].

Iakovidou, O. (1999). Agritourism and Traditional Agricultural Products Sales. Presentation in the 1st SAP of Central Macedonia Region.

Ilbery, B., Bowler, I., Clark, G., Crockett, A., \& Shaw, A. (1998). Farm based tourism as an alternative farm enterprise: a case study from the Northern Pennines, England. Regional Studies, 32 (4), 355-364.

Joint Ministerial Decision 12528 / 30-7-2018

Joint Ministerial Decisions B 1145/ 3-4-2017

Katsoni V., Dionysopoulou P., «Agritourism Marketing Distribution Strategy and Typology Investigation. The Case of Arcadia», TOURISMOS: An International Multidisciplinary Journal of Tourism, Volume 10, Number 2, Autumn Winter 2015, p.p. 131-152, UDC: $338.48+640(050)$.

Kilkis Development S.A. (AN.KI.), [online] Available at: www.anki.gr/, [Accessed 10/3/2018].

Kizos, T., \& Iosifides, T. (2007). The contradictions of agrotourism development in Greece: evidence from three case studies. South European Society and Politics, 12, 59-77.

Law 1698/1919 (Gaz. A 11/18-1-1919)

Law 241/1994 (Gaz. 111/A)

Law 3658/2008 (Gaz. A 70/22-4-2008)

Law 3874/2010 (Gaz. A 151/6-9-2010)

Law 4015/2011 (Gaz. A 210/21-9-11)

Law 4276/2014 (Gaz. A 155 30-7-14)

Law 4279/2014 (Gaz. A 158/08-8-14)

Law 4384/2016 (Gaz. A 78/26-4-16)

Law 4399/2016 (Gaz. A 117/22-6-16)

Law 4582/ 2018 (Gaz. A 208/11-12-18)

Lobo, R.E.; G.E. Goldman, D. Jolly; B.D. Wallace; W.L. Schrader; S.A. Parker. (1999). "Agricultural Tourism Benefits Agriculture in San Diego County." California Agriculture 53(6),

Logothetis, M. (1988). Agritourism. Athens: Doric.

MacCannell, D. (1973). Staged authenticity: arrangements of social space in tourist settings. The American Journal of Sociology, 79, 589-603.

Maniatis, A. (2016). Is there a constitutional guarantee for tourism and hospitality?. 4th Panhellenic Conference "Economic and Legal

McGehee, N. G. (2007). An agritourism systems model: a Weberian perspective. Journal of Sustainable Tourism, 15, 111-124.

McGehee, N. G., \& Kim, K. (2004). Motivation for agri-tourism entrepreneurship. Journal of Travel Research, 43, 161-170.

McKenzie, N., \& Wysocki, A. (2002). Agritainment: A viable option for Florida producers. IFAS Extension e University of Florida.

Ministry of Agricultural Development and Food, [online] Available at: http://www.minagric.gr/index.php/el/for-farmer-2/agritourism, [Accessed 5/2/2018].

Ministry of Agricultural Development and Food, [online] Available at: www.minagric.gr/index.php/el/for-farmer2/agritourism/agricultural, [Accessed 5/2/2018].

Ministry of Agricultural Development and Food, Program of Agricultural development 2007-2013, [online] Available at: www.archive.agrotikianaptixi.gr/ [Accessed 5/2/2018].

Ministry of Agricultural Development and Food, Program of Agricultural development 2014-2020, [online] Available at: www.agrotikianaptixi.gr, www.agroxenia.net/protaseis-giathesmikesrythmiseis-ston-agritourismo-20105/2/2018]. [Accessed 15/2/2018].

Ministry of Tourism, Available at: www.mintour.gov.gr/Ministry/VisionMission/[Accessed $5 / 6 / 2018]$.

Mousis, N., (2001), European Union- Law, Economics, Politics, Papazissi Editions, Athens.

Natural Environment White Paper 2011, [online] Available at: www.gov.uk/defra, [Accessed 7/2/2018]. 
Natural Environment White Paper 2014, [online] Available at: www.gov.uk/defra, [Accessed $5 / 2 / 2018]$.

Nickerson, N. P., Black, R. J., \& McCool, S. F. (2001). Agritourism: motivations behind farm/ranch business diversification. Journal of Travel Research, 40, 19-26.

Official Government Gazette of the Hellenic Republic 32/A/2014. Administrative measures, procedures and penalties of the EU and the national legislation in the field of food, feed and the animal health and protection and other provisions falling within the remit of the Ministry of Rural Development and Food, Law 4235, Athens, 2014.

Organization for Economic Co-operation and Development-OECD (2001). Glossary of statistical terms. Available at: http://stats.oecd.org/glossary/detail.asp?ID=72 [Assessed 6/2/2018]

Parameters of Greek Tourism", 15-17 September 2016, Tripoli. $\quad$ www.minagric.gr/index.php/el/forfarmer-2/agritourism. [Accessed 15/11/2017].

Parnon Developmental S.A.- Local Government Organization., [online] Available at: www.parnonas.gr/epileximes-dapanes-ypodraseon-idiotikou-charaktira/, [Accessed 20/2/2018].

Phillip, S., Hunter, C., \& Blackstock, K. (2010). A typology for defining agritourism. Tourism Management, 31, 754-758.

Sonnino, R. (2004). For a 'Piece of Bread'? Interpreting sustainable development through agritourism in Southern

Tew, C., \& Barbieri, C. (2012). The perceived benefits of agritourism: the provider's perspective. Tourism Management, 33 (1), 215-224.

Treaty of Lisbon amending the Treaty on European Union and the Treaty establishing the European Community, signed at Lisbon, 13 December 2007 OJ C 306, 17.12.2007, p. 1-271.

Tuscany. Sociologia Ruralis, 44, 285-300.

Weaver, D., \& Fennell, D. (1997). The vacation farm sector in Saskatchewan: a profile of operations. Tourism Management, 18(6), 357-365.

Wicks, B., \& Merrett, C. (2003). Agritourism: an economic opportunity for Illinois. Rural Research Report, 14 (9), 1-8.

Wikipedia Available at www.el.wikipedia.org/wiki/. The common agricultural policy [Accessed $5 / 6 / 2018]$.

Wilson, J., Thilmany, D., \& Sullins, M. (2006). Agritourism: A potential economic driver in the rural west. Economic Development Report. Colorado State University.

www.agroxenia.net/protaseis-gia-thesmikes rythmiseisstonagritourismo-2010 [Accessed 5/2/2018].

www.agroxenia.net/sxedio-diatypwsis-kritiriwn-aksiologisis-touristikwn-epixeirisewn $[$ Accessed $5 / 2 / 2018]$ 